\title{
Smart city trend in Tehran
}

\author{
Valiollah Nazari ${ }^{*}$, Mohammad Gholami ${ }^{2}$, Mohammad Mehdi Fooladi ${ }^{3}$, Alireza \\ Majorzadehzahiri ${ }^{4}$ and Eilaf Mourad Alashkar ${ }^{4}$ \\ ${ }^{1}$ Frarhangian University, Geography and Urban Planning Department, Karaj, Iran \\ ${ }^{2}$ Payame Noor University, Geography and Urban Planning Department, Karaj, Iran \\ ${ }^{3}$ Islamic Azad University, Urban Planning Department, Qazvin, Iran \\ ${ }^{4}$ Moscow State University of Civil Engineering, Yaroslavskoe shosse, 26, Moscow, 129337, Russia
}

\begin{abstract}
Cities are inherently complex and vastly interrelated challenges. Meanwhile, the rapid growth of cities is not commensurate with the capacity to expand their infrastructure and imposes increasing pressure on urban infrastructure. In other words, it is beyond their capacities and capabilities. Therefore, they always suffer from adverse consequences. One of the new concepts to meet the current challenges of cities in the field of urban planning is the development of smart cities that integrate physical and virtual capabilities. The trend of smart cities in Tehran has started a few years ago. In this study, the current situation of Tehran was evaluated and the strengths and weaknesses of Tehran Smart City were identified, and appropriate strategies and measures to continue the trend of moving Tehran City towards Smart City. The research method in this research is descriptive-analytical. SWOT analysis method and internal matrices (IFE) and external (EFE) were used for research. The results of this study show that all the necessities that have led cities in the world to smart approaches are also applicable in Tehran and the situation of Tehran in the trend of smart city in Tehran is appropriate. According to the strategy selected in this research, which is the Maxi-Maxi or SO strategy, the city of Tehran can continue the smart city trend by using its strengths and investing in opportunities and achieve the desired goals.
\end{abstract}

\section{Introduction}

The third millennium is the urban millennium; Because for the first time, the world's urban population exceeds $50 \%$. The magnitude and speed of contemporary accelerated urbanization are such that it is referred to as the second wave of urbanization. Meanwhile, the growth of urbanization with the beginning of the third millennium, which is the era of information technology in various areas of urban life, has taken a faster pace than in the past, which may be called the third wave of urbanization; Urbanization is projected to increase to more than $70 \%$ of the world's population by 2050 . Therefore, the process of early urbanization of the world is an inevitable reality. The 12th century is the century of cities, so cities play a pivotal role in the economy and are the driving force in global competition, information, development, and innovation, and are becoming globally integrated poles and more

\footnotetext{
*Corresponding author: v.nazari@cfu.ac.ir
} 
influential and responsible service-based societies. They are also a place for the concentration of physical and human capital, with 80 percent of the world's GDP coming from cities, and by 2050,600 of the world's largest cities are projected to produce 60 percent of the world's gross domestic product. But urbanization, despite great achievements for human beings, has brought with it problems and issues that, despite great scientific and technical advances, the solution of many of these problems have been accompanied by failure. Cities currently consume $75 \%$ of global energy and generate large amounts of waste and $70 \%$ of greenhouse gas emissions from cities, which play a major role in climate change. They have air and environmental pollution. On the other hand, the rapid growth of cities is not commensurate with the capacity to expand their infrastructure and imposes increasing pressure on urban infrastructure. Therefore, they always suffer from adverse consequences. This situation is more complicated in developing countries, including Iran, which is under increasing pressure to provide more and better basic services to the growing population. Hence, cities are inherently facing complex and wide-ranging interrelated challenges that can only be addressed through a systematic approach. In other words, the massive influx of residents has led to chaos and disorder, creating conditions that have not only upset the balance of cities but also made it impossible to achieve sustainability with current methods of urban management and development.[1-6]

The smart city is a model of urban development that arises from the interaction of different characters and represents a range of different goals and characteristics. The concept of a smart city primarily examines the city as a system that has multiple subsystems. This function of the subsystem as a whole ultimately allows them to behave intelligently and harmoniously, in other words, as the city is a complex system consisting of diverse and unpredictable interrelationships between Its subsystems. The goal of the smart cities model is to find appropriate solutions to manage this complexity, especially by solving the negative consequences of global urbanization and a higher quality of life for the urban population. The ultimate goal of the smart city is to provide smart services in all the vital capabilities of the city. The smart city is not a purely technical and economic issue, but a social system in which multiple independent stakeholders compete to achieve their goals. There are different views in the literature in this regard. Some authors have focused on producing better policy outcomes in terms of wealth, health, and sustainability. Others have focused on strengthening citizen participation and open forms of cooperation. The first view focuses on the content of government actions. While the second view emphasizes the processes of governance. [7-16]

The city of Tehran is the capital of Iran and the largest city (Fig. 1) with a population of 869,3706 people and $17.4 \%$ of the country's urban population in 2020 and the center of population attraction in the country and also due to its transnational role has a special place among cities. The high concentration of population in this city has caused it to face a multitude of complex issues and problems, including pollution, traffic, etc., despite the concentration of various facilities and services. Most of these problems are related to the way the city is run and the lack of attention to the real requirements and needs of the city (local, national and global). In the meantime, the idea of a smart city and cyberspace can be used to reduce the problems of the city with the help of real space and to improve the quality of life of citizens in various dimensions, and to strengthen Tehran's transnational status and role due to global connectivity of cities. Tehran Smart City program is designed in two phases, the first phase of which has started in 2018, and various researches to explain the necessities and requirements of Tehran to become smart in different dimensions, as well as providing appropriate strategies and measures to move Tehran towards a smart city. There have been. The researchers also identified the first ten characteristics of the smart city of Tehran based on the results (Table 1). The purpose of this study is to investigate the current situation of the smart city in Tehran and determining the appropriate strategy to continue the smart city trend in Tehran because without a clear understanding of the situation of Tehran in the urban 
smartening trend (which reflects its conditions and characteristics) can not determine the impact of the smart city on the quality of life of citizens and made the necessary decisions on how to continue the trend of smartening the city.[16-20]

Table 1. first ten characteristics of the smart city of Tehran.

\begin{tabular}{|c|c|c|c|}
\hline Rating & Feature & Component & Point \\
\hline 1 & Intelligent Water Resources Management & Smart environment & 31.99 \\
\hline 2 & Prospects in resource management & Smart environment & 31.62 \\
\hline 3 & Efficient transportation & Smart shipping & 31.24 \\
\hline 4 & Citizens' access to health services & Smart governance & 31.17 \\
\hline 5 & Physical infrastructure (road The, Rail lines,..) & Smart shipping & 30.98 \\
\hline 6 & Easy access to public and local transportation & Smart shipping & 29.3 \\
\hline 7 & Application of information and communication & Smart economy & 29.16 \\
\hline 8 & technology infrastructure & & \\
\hline 9 & The integrity of the infrastructure of the city & Smart environment & 28.84 \\
\hline 10 & Intelligent Energy Management & Smart environment & 28.55 \\
\hline
\end{tabular}

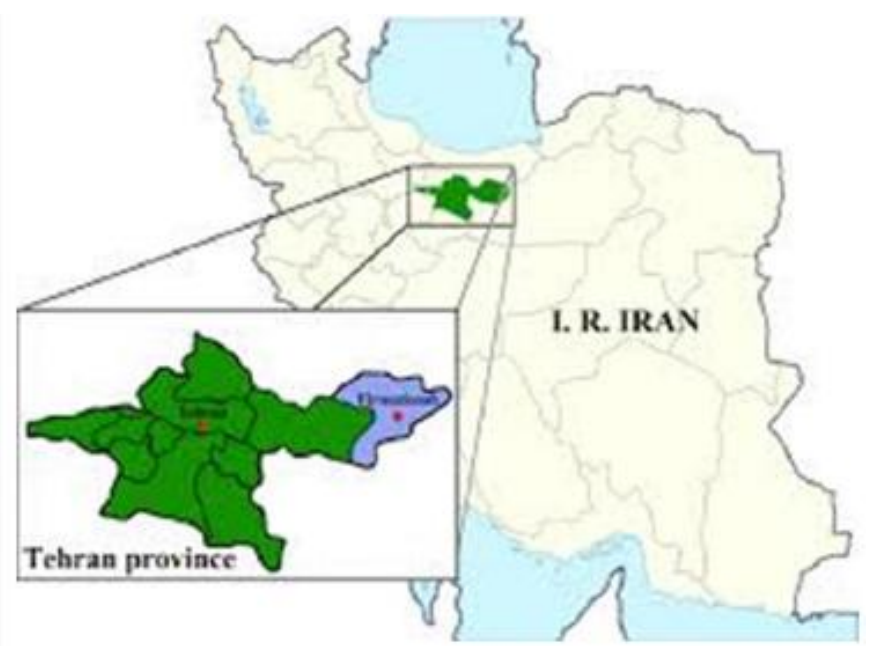

Fig. 1. Location of Tehran

\section{Methods}

This study uses a descriptive-analytical method based on documentary and library information. Based on theoretical and experimental research and taking into account the territorial and spatial dimensions of the subject (Tehran Smart City), the field research method and data collection through a questionnaire have been used.

This study used SWOT (Strengths, Weaknesses, Opportunities, and Threats) analysis to identify and comprehensively analyze the development opportunities and constraints for the Tehran Smart City project.

SWOT analysis is a structured planning method that can be used to evaluate the strengths, weaknesses, opportunities, and threats associated with a project such as a smart city and sustainable urban development.

SWOT analysis can be done for a city, place, industry, or person. This includes defining the smart city in the project and identifying favorable internal and external factors to achieve a smart city. 
Unlike previous decades, the appearance of cities, especially metropolises, has changed from traditional and classical to systematic and intelligent, and achieving it largely depends on internal strengths and weaknesses. Therefore, the use of a model that can provide a comprehensive analysis of the opportunities and limitations of the current situation of the city by identifying internal and external factors, is inevitable. [21,22]

In this study, a public survey was conducted, the survey results were processed, and conclusions were drawn based on the applied SWOT analysis.

\section{Results and Discussion}

To evaluate the current situation of the smart city in Tehran, the SWOT analysis method has been used, which in this study includes a three-step process.

\subsection{Identify internal and external factors}

Based on the SWOT model, Tables 2, 3, 4, and 5 have been prepared, which identify the internal and external factors affecting the smartening trend in Tehran.

In SWOT analysis, its internal factors are factors that can affect the purpose of the analysis itself, such as the quality of urban life.

External factors are factors that can affect the subject of analysis but are not controlled by it, such as urban policies, urban investment, regional migration, and natural disasters.

Using the matrix of internal and external factors, the selected research criteria are divided into internal and external aspects and are summarized in Tables 2 and 3. Table 2 shows the combination of internal factors that determine strengths and weaknesses.

Table 2. Selected criteria matrix of Internal factors of Smart City in Tehran Based on SWOT Model.

\begin{tabular}{|c|c|}
\hline Strengths & Weaknesses \\
\hline $\begin{array}{l}\text { S1.Tehran uses new and effective financial } \\
\text { models. } \\
\text { S2.Tehran society can produce goods and } \\
\text { services. } \\
\text { S3.Tehran now can leverage existing human } \\
\text { resources to create innovative solutions } \\
\text { S4.People have easy access to public transport } \\
\text { S5.People, goods, and vehicles are efficiently } \\
\text { transported in an urban environment in Tehran } \\
\text { S6.Different transport systems can be used in } \\
\text { Tehran } \\
\text { S7.The use of communication and information } \\
\text { technologies in the daily activities of Tehran } \\
\text { residents is high. } \\
\text { S8.Suitable conditions and conditions are } \\
\text { provided for the night presence of people in the } \\
\text { urban community of Tehran } \\
\text { S9.Tehran citizens are active in society } \\
\text { S10.Tehranians' Access to Smart City Facilities } \\
\text { Improves Quality of Life }\end{array}$ & $\begin{array}{l}\text { W1.Tehran officials can collect taxes from } \\
\text { citizens for utilities. } \\
\text { W2." Education level" is not high for all } \\
\text { citizens of Tehran } \\
\text { W3. The level of participation of Tehran } \\
\text { residents in the public affairs of the city is high. } \\
\text { W4.Industries and companies in Tehran do not } \\
\text { use the scientific potential of universities in } \\
\text { their activities. } \\
\text { W5.Transport systems in Tehran are supported } \\
\text { by appropriate information and communication } \\
\text { technologies } \\
\text { W6.Tehran uses technology to manage and } \\
\text { monitor citizens' health } \\
\text { W7.City-related data and information is easily } \\
\text { accessible to citizens } \\
\text { W8.Adequate land-use planning and mixing of } \\
\text { land-use are not carried out in Tehran. } \\
\text { W9. Water resources in Tehran are not managed } \\
\text { properly and wisely } \\
\text { W10.Tehran has no integrated infrastructure }\end{array}$ \\
\hline
\end{tabular}

Table 3 shows the external factors that determine the opportunities and threats of the smart city in Tehran. 
Table 3. Selected criteria matrix of external factors of Smart City in Tehran based on the SWOT model.

\begin{tabular}{|c|c|}
\hline Opportunities & Threats \\
\hline $\begin{array}{l}\text { O1.Tehran is a dynamic and productive city with } \\
\text { countless economic opportunities for wealth } \\
\text { creation. } \\
\text { O2.Tehran has the opportunity to attract trade and } \\
\text { capital for the economic development of citizens. } \\
\text { O3.Tehran society encourages "creativity and } \\
\text { innovation" } \\
\text { O4.There are many tourist attractions in the city } \\
\text { of Tehran. } \\
\text { O5.Electronic government services are } \\
\text { widespread in Tehran. } \\
\text { O6.Availability and growth of smart, sustainable, } \\
\text { and environmentally friendly buildings in Tehran } \\
\text { O7.Tehran has effective bandwidth for the use of } \\
\text { information technology. } \\
\text { O8.24 hour service process in Tehran is } \\
\text { increasing } \\
\text { O9.The use of urban spaces in Tehran is being } \\
\text { improved through smart design } \\
\text { O10.Tehran's urban safety grows thanks to smart } \\
\text { city security controls }\end{array}$ & $\begin{array}{l}\text { T1. Tehran's economy is not based on } \\
\text { knowledge, innovation, and creativity } \\
\text { T2. Tehran society does not care about } \\
\text { entrepreneurship. } \\
\text { T3. The variety of services offered to citizens } \\
\text { in Tehran is not great } \\
\text { T4. The quality of housing in Tehran is not } \\
\text { very good and not all sectors of society have } \\
\text { access to it. } \\
\text { T5.The level of cooperation and the presence } \\
\text { of people in the urban affairs of Tehran is } \\
\text { high. } \\
\text { T6.Citizens do not play a role in Tehran's } \\
\text { decision-making. } \\
\text { T7.Tehran lacks integrated urban governance } \\
\text { and inter-agency coordination } \\
\text { T8.Energy resources are not wisely managed } \\
\text { in Tehran. } \\
\text { T9.New and renewable energy is not being } \\
\text { used to meet Tehran's needs. } \\
\text { T10.In Tehran, the production of polluting } \\
\text { gases by industry is not regulated. }\end{array}$ \\
\hline
\end{tabular}

\subsection{Assign the weights and ratings}

Each factor should be assigned a weight in the range from 0.0 (low importance) to 1.0 (high importance). This number shows the importance of each factor in reaching the smart city. The sum of all Weights must be equal to 1.0. Ratings in the internal matrix refer to how strong, weak, opportunities, or threats each factor is in a city. These numbers vary from 4 to 1, where 4 means a major strength or opportunities, 3 - minor strength or opportunities, 2 minor weakness or threats, and 1 - major weakness or threats. Strengths or opportunities can only get ratings of 3 and 4 , weaknesses or threats- 2 and 1 .

Table 4, based on the data in Table 2, presents the internal factors evaluated using the evaluation matrix.

Table 4. Intra-Factor Evaluation matrix (IFE).

\begin{tabular}{|c|c|c|c|}
\hline Internal strategic factors & Weight & Rating & $\begin{array}{c}\text { Weighted } \\
\text { Score }\end{array}$ \\
\hline W1.Tehran officials can collect taxes from citizens for utilities. & 0.054 & 2 & 0.108 \\
\hline W2." Education level" is not high for all citizens of Tehran & 0.048 & 2 & 0.096 \\
\hline $\begin{array}{c}\text { W3. The level of participation of Tehran residents in the public } \\
\text { affairs of the city is high. }\end{array}$ & 0.027 & 2 & 0.054 \\
\hline $\begin{array}{c}\text { W4.Industries and companies in Tehran do not use the scientific } \\
\text { potential of universities in their activities. }\end{array}$ & 0.027 & 2 & 0.054 \\
\hline $\begin{array}{c}\text { W5.Transport systems in Tehran are supported by appropriate } \\
\text { information and communication technologies }\end{array}$ & 0.054 & 2 & 0.108 \\
\hline $\begin{array}{c}\text { W6.Tehran uses technology to manage and monitor citizens' } \\
\text { health }\end{array}$ & 0.048 & 3 & 0.144 \\
\hline $\begin{array}{c}\text { W7.City-related data and information is easily accessible to } \\
\text { citizens }\end{array}$ & 0.054 & 2 & 0.108 \\
\hline
\end{tabular}




\begin{tabular}{|c|c|c|c|}
\hline $\begin{array}{c}\text { W8.Adequate land-use planning and mixing of land-use are not } \\
\text { carried out in Tehran. }\end{array}$ & 0.067 & 2 & 0.134 \\
\hline $\begin{array}{c}\text { W9.Water resources in Tehran are not managed properly and } \\
\text { wisely }\end{array}$ & 0.048 & 3 & 0.144 \\
\hline W10.Tehran has no integrated infrastructure & 0.054 & 2 & 0.108 \\
\hline S1.Tehran uses new and effective financial models. & 0.067 & 4 & 0.268 \\
\hline S2.Tehran society can produce goods and services. & 0.054 & 3 & 0.162 \\
\hline $\begin{array}{c}\text { S3.Tehran now can leverage existing human resources to create } \\
\text { innovative solutions }\end{array}$ & 0.054 & 3 & 0.162 \\
\hline S4.People have easy access to public transport & 0.067 & 3 & 0.201 \\
\hline $\begin{array}{c}\text { S5.People, goods, and vehicles are efficiently transported in an } \\
\text { urban environment in Tehran }\end{array}$ & 0.054 & 3 & 0.162 \\
\hline S6.Different transport systems can be used in Tehran & 0.048 & 3 & 0.144 \\
\hline $\begin{array}{c}\text { S7.The use of communication and information technologies in the } \\
\text { daily activities of Tehran residents is high. }\end{array}$ & 0.067 & 3 & 0.201 \\
\hline $\begin{array}{c}\text { S8.Suitable conditions and conditions are provided for the night } \\
\text { presence of people in the urban community of Tehran }\end{array}$ & 0.054 & 3 & 0.162 \\
\hline S9.Tehran citizens are active in society & 0.027 & 3 & 0.081 \\
\hline $\begin{array}{c}\text { S10.Tehranians' Access to Smart City Facilities Improves Quality } \\
\text { of Life }\end{array}$ & 0.027 & 3 & 0.081 \\
\hline Total (IFE). & 1.000 & & 2.682 \\
\hline
\end{tabular}

Table 5 shows the external factors estimated using the evaluation matrix based on the data in table 3.

Table 5. External-Factor Evaluation matrix (EFE).

\begin{tabular}{|c|c|c|c|}
\hline $\begin{array}{c}\text { External strategic factors } \\
\begin{array}{c}\text { T1. Tehran's economy is not based on knowledge, innovation, and } \\
\text { creativity }\end{array}\end{array}$ & 0.071 & 2 & 0.142 \\
\hline T2. Tehran society does not care about entrepreneurship. & 0.057 & 2 & 0.114 \\
\hline $\begin{array}{c}\text { T3. The variety of services offered to citizens in Tehran is not } \\
\text { great }\end{array}$ & 0.042 & 2 & 0.084 \\
\hline $\begin{array}{c}\text { T4.The quality of housing in Tehran is not very good and not all } \\
\text { sectors of society have access to it. }\end{array}$ & 0.071 & 2 & 0.142 \\
\hline $\begin{array}{c}\text { T5.The level of cooperation and the presence of people in the } \\
\text { urban affairs of Tehran is high. }\end{array}$ & 0.071 & 2 & 0.142 \\
\hline T6.Citizens do not play a role in Tehran's decision-making. & 0.057 & 2 & 0.114 \\
\hline $\begin{array}{c}\text { T7.Tehran lacks integrated urban governance and inter-agency } \\
\text { coordination }\end{array}$ & 0.042 & 2 & 0.084 \\
\hline T8.Energy resources are not wisely managed in Tehran. & 0.042 & 2 & 0.084 \\
\hline $\begin{array}{c}\text { T9.New and renewable energy is not being used to meet Tehran's } \\
\text { needs. }\end{array}$ & 0.071 & 2 & 0.142 \\
\hline $\begin{array}{c}\text { T10.In Tehran, the production of polluting gases by industry is } \\
\text { not regulated. }\end{array}$ & 0.057 & 3 & 0.171 \\
\hline $\begin{array}{c}\text { O1.Tehran is a dynamic and productive city with countless } \\
\text { economic opportunities for wealth creation. }\end{array}$ & 0.042 & 3 & 0.126 \\
\hline $\begin{array}{c}\text { O2.Tehran has the opportunity to attract trade and capital for the } \\
\text { economic development of citizens. }\end{array}$ & 0.042 & 4 & 0.168 \\
\hline O3.Tehran society encourages "creativity and innovation" & 0.034 & 3 & 0.102 \\
\hline O4.There are many tourist attractions in the city of Tehran. & 0.042 & 3 & 0.126 \\
\hline O5.Electronic government services are widespread in Tehran. & 0.034 & 3 & 0.102 \\
\hline $\begin{array}{c}\text { O6.Availability and growth of smart, sustainable, and } \\
\text { environmentally friendly buildings in Tehran }\end{array}$ & 0.042 & 3 & 0.126 \\
\hline
\end{tabular}




\begin{tabular}{|c|c|c|c|}
\hline $\begin{array}{c}\text { O7.Tehran has effective bandwidth for the use of information } \\
\text { technology. }\end{array}$ & 0.042 & 3 & 0.126 \\
\hline O8.24 hour service process in Tehran is increasing & 0.042 & 4 & 0.168 \\
\hline $\begin{array}{c}\text { O9.The use of urban spaces in Tehran is being improved through } \\
\text { smart design }\end{array}$ & 0.057 & 3 & 0.171 \\
\hline $\begin{array}{c}\text { O10.Tehran's urban safety grows thanks to smart city security } \\
\text { controls }\end{array}$ & 0.042 & 4 & 0.168 \\
\hline \begin{tabular}{c} 
Total (EFE). \\
\hline
\end{tabular} & 1.000 & & 2.602 \\
\hline
\end{tabular}

\subsection{Formation of internal-external matrix}

The IFE or EFE matrices themselves have little value. Both analyses should be carried out and their results combined to discuss new strategies or for further analysis. They are particularly useful when building an extended SWOT analysis, IE matrix.

To get results, the overall IFE indicator is laid horizontally on the (IE) matrix, and the overall EFE indicator is laid vertically. and the intersection point of the indicator values is located.

According to Tables 4 and 5, the total of internal factors is equal to 2.682 and the total of external factors is equal to 2.602. The intersection point of this total of internal and external factors is shown in Figure 2.

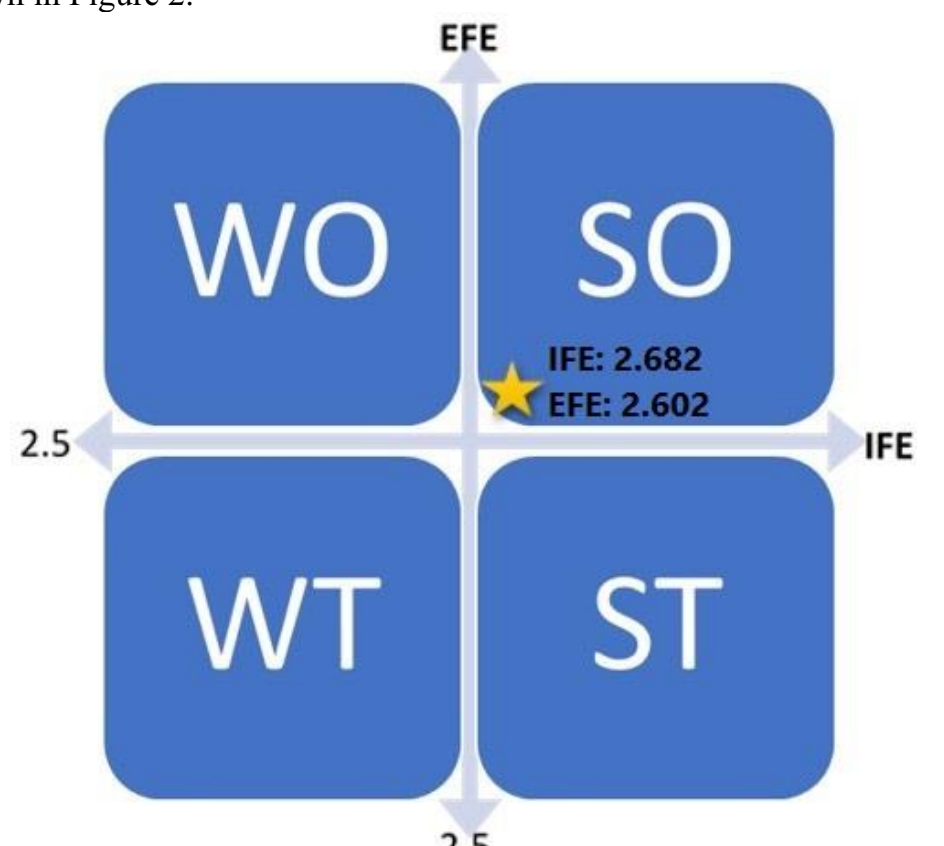

2.5

Fig. 2. Internal and External Evaluation Strategy (IE) for Smart City in Tehran based on SWOT

Figure 2 shows the IE diagram based on SWOT where:

WO 'Mini-Maxi' Strategy (Strategies that minimize weaknesses by taking advantage of opportunities).

SO 'Maxi-Maxi' Strategy (Strategies that use strengths to maximize opportunities).

WT 'Mini-Mini' Strategy (Strategies that minimize weaknesses and avoid threats).

ST 'Maxi-Mini' Strategy (Strategies that use strengths to minimize threats).

Based on Figure 2, the IE matrix in the SWOT diagram, it is concluded that the smart city trend in Tehran is the most appropriate strategy SO "Maxi-Maxi". The Maxi-Maxi strategy 
approach is to use internal strengths to make the most of the external opportunities available to the city.

\section{Conclusions}

The formation of a smart city requires integrated actions at different levels of government and urban communities. The smart city is a holistic concept that aims to meet the contemporary challenge and take advantage of recent opportunities offered by advances in information and communication technology and urbanization.

The smart city process in Tehran started a few years ago. In this process, first, the requirements and indicators of the smart city in all six characters of the smart city were determined and the priorities of the smart city of Tehran were determined. In this study, by evaluating the current situation of the smart city in Tehran, the strengths and weaknesses, as well as the opportunities and threats facing the city of Tehran in the smart city trend, were identified. The results obtained from the analysis of internal (IFE) and external (EFE) matrices and evaluation of the IE matrix based on the SWOT method showed the best strategy to continue the smart city trend in Tehran, the Maxi-Maxi strategy or SO. In this strategy, the city of Tehran must complete the smart city trend by taking advantage of its strengths and investing in opportunities.

Based on the research results and following the strategy specified in this research, the following suggestions are presented to advance the smart city trend in Tehran.

$>$ Build a solid bridge between government agencies.

$>$ Improve access to technology services.

$>$ Develop and improve electronic banking.

$>$ Using information technology to reduce paperwork.

$>$ Garbage must be separated and recycled.

$>$ Using new technologies to reduce energy consumption.

$>$ Help to preserve the rural population.

$>$ Expand smart transportation system.

$>$ Reducing traffic congestion by making city graphs easier.

$>$ Expand smart city infrastructure.

$>$ The green space must develop and expand.

$>$ Provide public internet access.

$>$ Using information and communication technology to become more influential.

$>$ Providing conditions for remote control of the house using a warning system or a warning system for residents.

$>$ Creation of an electronic health card available to citizens.

$>$ Online medical services are being created and developed.

$>$ Provide virtual and distance learning to inform more citizens.

$>$ Improving educational services in urban and rural areas with smart technology.

$>$ Continuous collaboration between companies and knowledge centers.

$>$ Improve the quality of education.

$>$ Provide energy-saving conditions, resources, time with smart technology.

$>$ Expand the use of smart technologies to provide 24/7 services to citizens.

$>$ Smart control systems reduce air pollution as well as reduce the use of private cars and optimize smart public transport.

$>$ With the smart urban design, urban spaces can be used for many purposes.

$>$ The use of urban land has been improved and the use of urban land has been reduced.

$>$ Help protect the environment and ecosystems with smart management 


\section{References}

1. S. Crivello, Urban Policy Mobilities: The Case of Turin as a Smart City, European Planning Studies, 23(5), 909-921 (2014)

2. A. Alawadhi, H. Aldama, J.R. Chourabi, S. Garcia, S. Leung, T. Mellouli, T. M. Nam, H. J. Pardo, S. Scholl, Building Understanding of Smart City Initiatives, Lecture Notes in Computer Science, 7443, 40-53 (2012)

3. V. Albino, U. Beradi, R. M. Dangelico, Smart Cities: Definitions, Dimensions, Performance, and Initiatives, Journal of Urban Technology, 22(1), 3-21 (2015)

4. S. Allwinkle, Cruickshank, Creating Smart-er Cities: An Overview, Journal of Urban Technology, 18, 1-16 (2011)

5. L. Bătăgan, Smart Cities and Sustainability Models, InformaticaEconomica, (2009) 15(3), 80-87 (2011)

6. H. Scholl, M. Scholl, Smart governance: A roadmap for research and practice, in Proceedings of the iSchools Conference, Berlin, Germany, 163-176 (2014)

7. S. Kim, S. M. Song, Y. I. Yoon, Smart learning services based on smart cloud computing, Sensors, 11(8), 7835-7850 (2011)

8. G. P. Hancke, G. P. Hancke Jr, The role of advanced sensing in smart cities, Sensors, 13(1), 393-425 (2012)

9. N. Yusof, J. Van Loon, Engineering a global city: The case of cyberjaya, Space and Culture, 15(4), 298-316 (2012)

10. D. Walters, Smart cities, smart places, smart democracy: Form-based codes, electronic governance and the role of place in making smart cities, Intelligent Buildings International, 3(3), 198-218 (2011)

11. W. Steffen, G. Jaques, C. Paul, M. John, The Anthropocene: conceptual and historical perpective, Philosophical Transactions of the Royal Society, 369, 842-867 (2011)

12. H. Schaffers, N. Komninos, M. Pallot, B. Trousse, M. Nilsson, A. Oliveira, In: J. Domingue et al. (Eds.): Future Internet Assembly, 6656, 431-446 (2011)

13. K. A. Paskaleva, Enabling the smart city: The progress of city e-governance in Europe, nternationalJournal of Innovation and Regional Development, 1(4), 405-422 (2009)

14. R. Martin, J. Simmie, Path dependence and local innovation systems in city-regions. Innovation: Management, Policy \& Practice, 10(2-3), 183-192 (2008)

15. S. Goldfinch, Pessimism, computer failure, and information systems development in the public sector, Public Administration Review, 67(5), 917- 929 (2007)

16. P. Jennings, Managing the risks of Smarter Planet solutions, IBM Journal of Research and Development, 54(4), 1-9 (2010)

17. E. Cosgrave, T. Tryfonas, Exploring the relationship between smart city policy and implementation, In The First International Conference on Smart Systems, Devices and Technologies, 79-82 (2012)

18. A. Coe, G. Paquet, J. Roy, E-governance and smart communities: a social learning challenge, Social science computer review, 19(1), 80-93 (2001)

19. A. Caragliu, C. Del Bo, Smartness and European urban performance: assessing the local impacts of smart urban attributes. Innovation, The European Journal of Social Science Research, 25(2), 97-113 (2012)

20. F. Bria, New governance models towards a open Internet ecosystem for smart connected European cities and regions, Open Innovation, 13, 62-71 (2012) 
21. A. Humphrey, "SWOT Analysis for Management Consulting" (PDF), SRI Alumni Newsletter, (2015)

22. M. Blake, S. Wijetilaka, "5 tips to grow your start-up using SWOT analysis", Retrieved, Sydney, (2015) 